\title{
Synchronous Tumors: Renal Cell Carcinoma with Adenocarcinoma of the Ampulla of Vater; Case Report
}

\author{
Senkron Tümörler: Renal Hücreli Karsinom ve Ampulla Vateri \\ Adenokarsinomu; Olgu Sunumu
}

\author{
Yavuz Onur DANACIOGLU $\odot$, Ferhat KeSER $\odot$, Pinar ERGIN ZERK $\odot$, Bengü COBANOGLU SIMSEK $\odot$, \\ Turgay TURAN $\odot$
}

Ethics Committee Aproval: Not Applicable.

Confillict of Interest: The authors declare that they have no conflict of interest. Funding: None.

Informed Concent: Informed consent was taken.
Cite as: Danacioglu YO, Keser F, Engin Zerk P, Cobanoglu Simsek B, Turan T. Synchronous Tumors: Renal Cell Carcinoma with Adenocarcinoma of the Ampulla of Vater; Case Report. Medeniyet Med J. 2019;34:208-12.

\begin{abstract}
Multiple tumors that occur at the same time are defined as synchronized tumors. Occurrence of renal cell carcinomas with synchronous tumors is a rare condition. A 79-year-old female presented with complaints of intermittent fever, anemia, loss of appetite and weight. Imaging studies revealed the presence of pancreatic lesion with proximal choledocal dilatation and a mass lesion in lower pole of the left kidney. The patient was treated successfully by open left partial nephrectomy for the renal cancer and pancreaticoduodenectomy with cholecystectomy for the pancreatic lesion. In this case report, a patient who has synchronous adenocarcinoma of ampulla of Vater and renal cell carcinoma will be presented.
\end{abstract}

Keywords: Multiple primary cancer, renal cell carcinoma, ampulla of Vater

öz

Eşzamanlı olarak saptanan çoklu kanserler senkron tümör olarak adlandırılmaktadır. Renal hücreli karsinomların senkron tümörlerle birlikte görülmesi nadir bir durumdur. Yetmiş dokuz yaşında kadın hasta aralıkı ateş, anemi, kilo kaybı ve iştah kaybı şikayetleri ile tarafımıza başvurdu. Yapılan görüntüleme yöntemleri ile koledok kanalı proksimalinde dilatasyonun eşlik ettiği pankreatik lezyon ve sol böbrek alt polde kitle belirlendi. Hastaya sol açık parsiyel nefrektomi ve kolesistektomi ile birlikte pankreoduodenektomi yapılarak başarılı şekilde tedavi uygulandı. Bu olgu sunumunda böbrek hücreli karsinom ile birlikte senkron ampulla vateri karsinomu tespit edilen bir vaka sunulacaktır.

Anahtar kelimeler: Multipl primer kanser, renal hücreli karsinom, ampulla of Vater
Received: 28.06 .2018

Accepted: 18.11 .2018

Online First: 10.06 .2019

Corresponding Author: Y.O. Danacioglu

ORCID: 0000-0002-3170-062X

Istanbul Medeniyet University,

Goztepe Training and Research

Hospital, Department of Urology, Istanbul - Turkey

dr_yonur@hotmail.com

F. Keser
T. Turan
ORCID: 0000-0002-2803-6481
ORCID: 0000-0002-4951-6396
Istanbul Medeniyet University,
Goztepe Training and Research
Hospital, Department of Urology,
Istanbul, Turkey
P. Engin Zerk
ORCID: 0000-0002-4292-6392
Okmeydanı Research and Training
Hospital, Department of Pathology,
Istanbul, Turkey
B. Cobanoglu Simsek
ORCID: 0000-0003-2639-2017
Istanbul Medeniyet University,
Goztepe Training and Research
Hospital, Department of Pathology,
Istanbul, Turkey

田

( ) Copyright Istanbul Medeniyet University Faculty of Medicine. This journal is published by Logos Medical Publishing. Licenced by Creative Commons Attribution-NonCommercial 4.0 International (CC BY-NC 4.0) 


\section{INTRODUCTION}

The incidence of multiple primary malignancies that are characterized as numerous tumors identified in an individual is increasing with time ${ }^{1,2}$. The coexistence of two or more tumors of different histopathologies at multiple sites is categorized into synchronous or metachronous neoplasms according to the time of diagnosis ${ }^{3}$. The incidence of multiple primary tumors ranges from $1 \%$ to $10 \%$. Metachronous tumors are more common malignancies than synchronous subcategories with a ratio 2.7: $1^{4}$. Kidney cancer is the tenth most common cancer for both genders 5 . Renal cell carcinoma (RCC) is the most mortal one of the frequently seen urinary tract cancers. The mortality rate of RCC is $30 \%-40 \%$ and accounts for $80 \%-85 \%$ of all kidney cancers ${ }^{6}$. Carcinoma of the ampulla of Vater is the second most common periampullary malignancy ${ }^{7}$. When carcinomas of the ampulla are compared to other periampullary pancreatic cancers, the resectability rate is higher and the prognosis is better in most series ${ }^{8}$. There are just a few cases in the available literature about coexistence of metastatic RCC with adenocarcinoma of ampulla of Vater, but there are no reports of resected synchronous RCC and adenocarcinoma of ampulla of Vater. To our knowledge, this is the first case of simultaneous resection of synchronous adenocarcinoma of ampulla of Vater and RCC.

\section{CASE}

A 79-year-old woman presented with complaints of intermittent fever, anemia, appetite and weight loss. She had a history of diabetes mellitus type 2 (DM) for 20 years. There was no significant family history. Her physical examination did not reveal any relevant signs except jaundice. Some laboratory test results were as follows: serum total bilirubin $12.33 \mathrm{mg} / \mathrm{dL}(0-1.2 \mathrm{mg} / \mathrm{dl})$, serum direct bilirubin $10.57 \mathrm{mg} / \mathrm{dL}(0.0-0.2 \mathrm{mg} / \mathrm{dl})$, complete blood count, amylase 509 U/L (28-100 U/L), lipase $469 \mathrm{U} / \mathrm{L}$ (0-60 U/L) and cancer antigen 125 (CA 125) $37.7 \mathrm{U} / \mathrm{ml}(0-35 \mathrm{U} / \mathrm{ml})$. During follow up, magnetic resonance cholangiopancreatography (MRCP) was performed with suspect of obstructive jaundice. Magnetic resonance imaging (MRI) of the abdomen demonstrated $11 \times 9 \mathrm{~mm}$ pancreatic lesion with proximal choledochal dilatation and a mass lesion in the lower pole of the left kidney suspected as RCC (Figure 1). Endoscopic biopsy

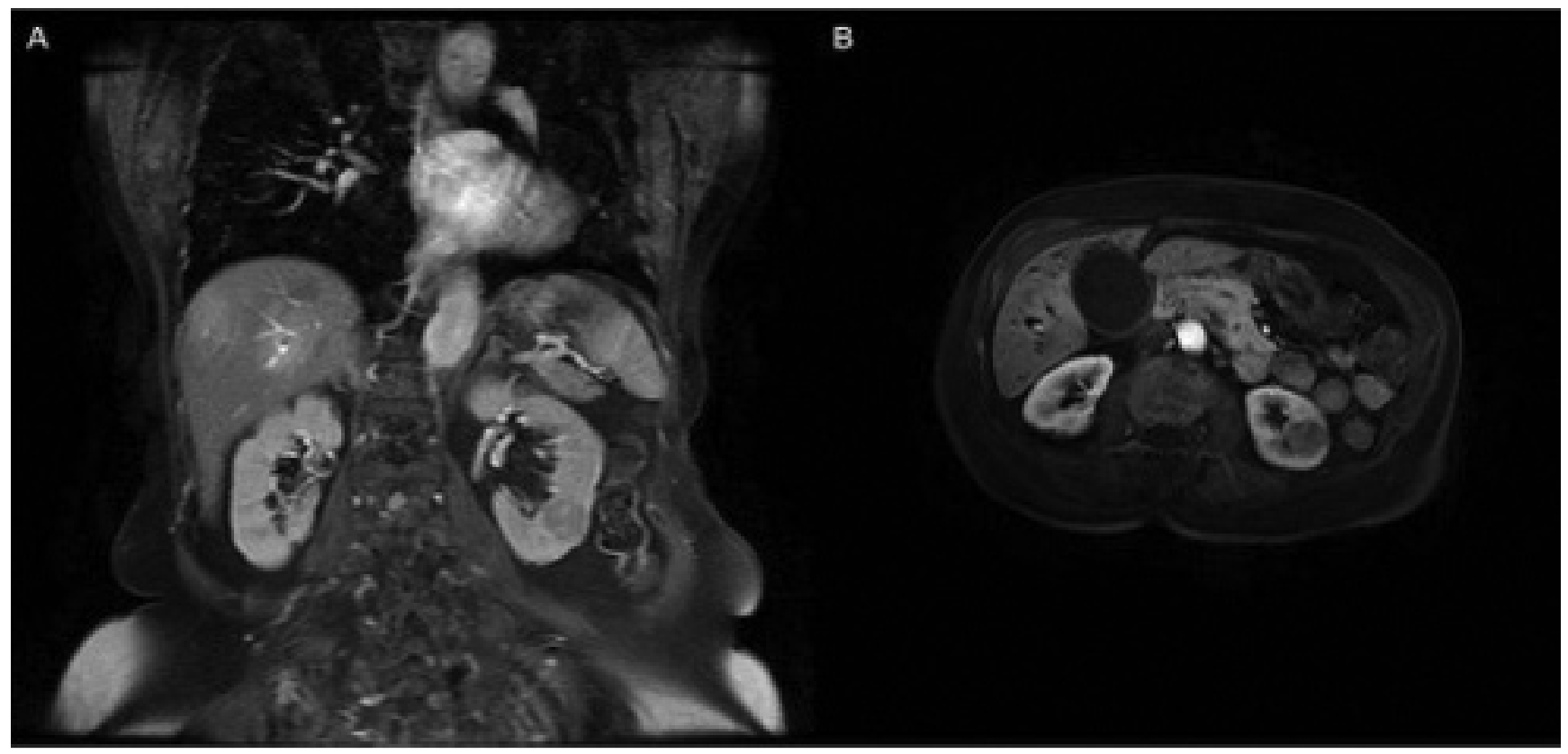

Figure 1. A-Coronal axis of MRI, left kidney lower zone lesion, B-Sagittal axis of MRI, left kidney lower zone lesion. 


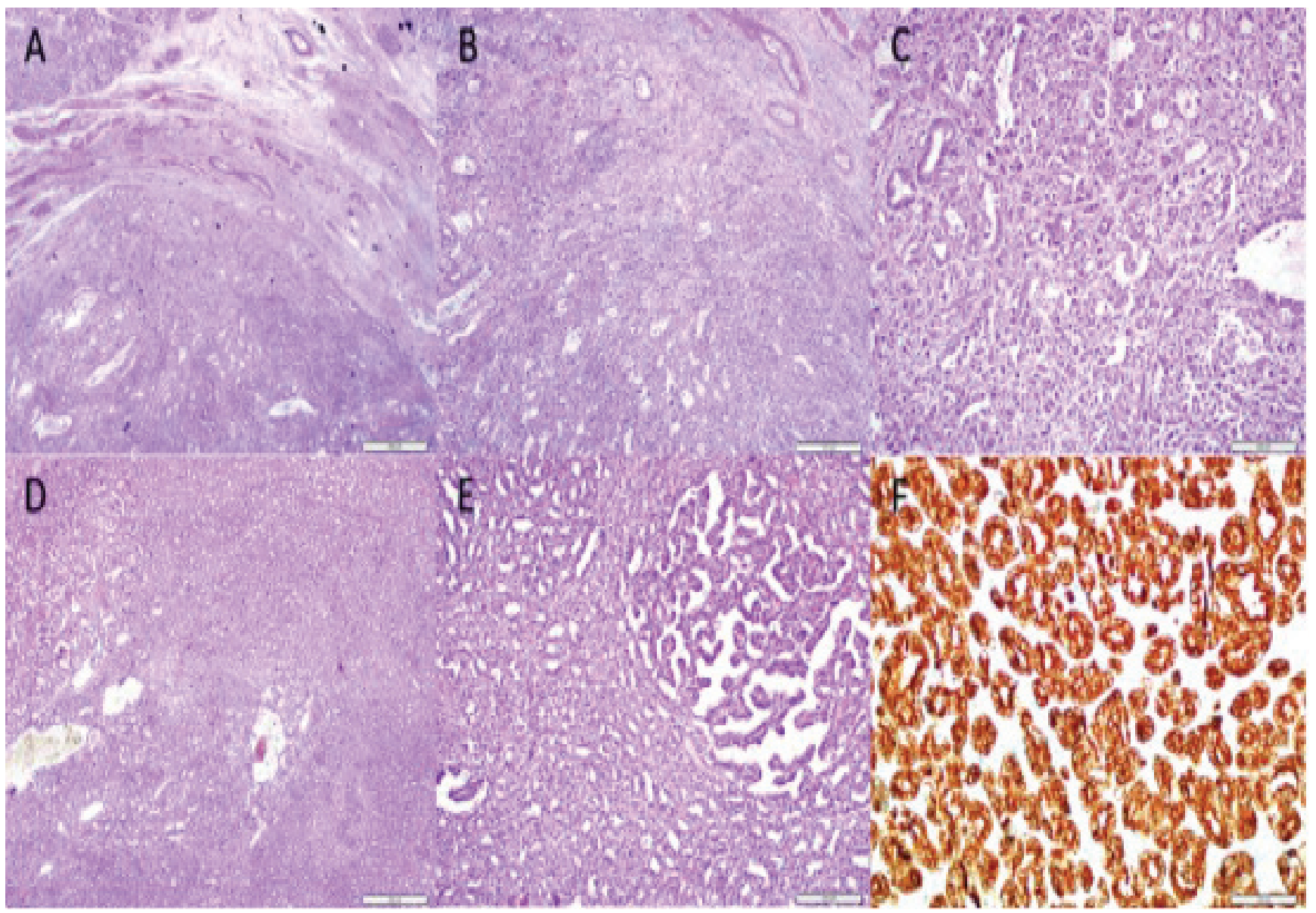

Figure 2. A-Tumoral lesion in ampulla of vater (H\&E x20); B-Adenocarcinoma, Grade 2 (Pancreoticobiliary type) (H\&E x10); C-Adenocarcinoma, Grade 2 (Pancreoticobiliary type) (H\&E x20); D-Tumoral mass composed of tightly packed tubules and occasional papillary structures in partial nephfrectomy specimen (H\&E x20); E-Papillary structures and tubules are lined by polygonal, cuboidal epithelial cells with granular eosinophilic cytoplasm (H\&E x10); F-CK 7 positivity in tumor cells (x20).

was performed from papilla of ampulla of Vater, and its histopathology was reported as a benign lesion. Positron emission tomography-computed tomography (PET-CT) showed renal cell and ampulla of Vater tumor without any other metastasis and lymphadenopathy. Pancreaticoduodenectomy, cholecystectomy and open left partial nephrectomy was performed together during the same session. After the operation, the patient was transferred to the intensive care unit for monitorization. Histopathological examination revealed papillary RCC with negative surgical margin and Grade 2 and T1NxMx stage adenocarcinoma of ampulla of Vater. The size of the renal lesion was measured as $4 \times 3 \times 1 \mathrm{~cm}$. In pancreaticoduodenectomy specimen, there was a white tumoral mass of $1 \times 0.7 \mathrm{~cm}$ filling the ampulla of Vater (A, Figure 2). Tumor was composed of simple or branching glands and small solid nests of cells surrounded by a desmoplastic stroma. Glands were formed with cuboidal and low columnar epithelium arranged in a single layer without nuclear pseudostratification (B, C, Figure 2 ). There was no invasion to duodenal wall or pancreatic tissue. Partial nephrectomy specimen was mostly composed of uniform tumoral cells forming small tubules and occasional papillary structures (D, Figure 2). Papillary structures and tubules are lined by polygonal, cuboidal epithelial cells with granular eosinophilic cytoplasm (E, Figure 2). Immunohistochemically, these cells were positively stained with CK7 and negatively with CD10 (F, Figure 2). The specimen 
was also stained with $\mathrm{CDX} 2$ as the patient had adenocarcinoma of ampulla of Vater to exclude a metastasis. But it was negatively stained with CDX2. In spite of the successful operation the patient died 4 days after the operation due to cardiac problems.

\section{DISCUSSION}

Synchronous adenocarcinoma of ampulla of Vater and renal cancer has not been reported in the literature. To our knowledge, two or more different synchronous primary tumors develop rarely. This is the first report of two primary tumors that includes ductal pancreatic adenocarcinoma and RCC which were both treated surgically at the same time. Our case presented with painless obstructive jaundice. The patient who has renal lesion may be presented with systemic and paraneoplastic symptoms frequently associated with nonmetastatic nephrogenic hepatic dysfunction syndrome (Stauffer'ssyndrome) that presents with anemia, thrombocytosis, cachexia, weight loss, fever, increased erythrocyte sedimentation rate (ESR), decreased serum-albumin concentration, abnormal liver function?. In patient with unexplained hepatic pathologies particularly when combined with systemic disease symptoms, we should perform further assessment for an underlying malignancy due to paraneoplastic cholestasis. Different diagnostic modalities can be performed to visualize the presence of an ampullary tumor. Abdominal ultrasonography (US), computed tomography (CT), MRI and PET-CT, endoscopic ultrasound (EUS) and endoscopy contribute greatly to diagnosis and staging of these tumors. Carbonhydrate antigen 19-9 (CA 19-9) is the gold-standard serum tumor marker used for the diagnosis of pancreatic cancer in symptomatic patients. An elevated level of CA 19-9 may help to guide the diagnosis towards an ampullary adenocarcinoma with a sensitivity of $81 \%$ and specificity of $89 \%{ }^{10}$. Biochemistry values showed elevation of the liver enzymes and CA 19-9 level. Transabdominal ultrasonography should be performed as the first imaging study that can differentiate between intrahepatic and extrahepatic bile duct dilatations however the ampullary tumor may not be detected. MRI including CP is the most predictive noninvasive diagnostic imaging modality for the assessment of ampullary tumors. However the ampulla of Vater has been defined as a blind spot for MRI because of its small size and the tapering of the ducts that comprise insufficient amount of fluid $^{11,12}$. At first, MRCP was applied in this case. Afterwards ERCP was performed to take a biopsy and confirm the diagnosis of the suspicious lesion. Histopathology of the biopsy specimen obtained with ERCP was reportedly benign. Then 18fluorodeoxyglucose (18-FDG) PET-CT was used to make the correct diagnosis. ERCP could not be performed successfully due to technical limitations in almost a quarter of patients with suspected ampullary carcinoma ${ }^{13}$. PET-CT showed FDG accumulation in the kidney and ampulla of Vater without any other accumulations of FDG elsewhere in her body. FDG PET-CT may be helpful to differentiate pancreatic adenomas from carcinomas but false positive results can be achieved in the presence of benign inflammatory conditions ${ }^{14}$. At first, ampullary carcinoma should be detected to identify the resectability of the lesions. If the lesion is proved by imaging techniques or by biopsy, the treatment options are pancreaticoduodenectomy or its modification for resectable tumors. This is the mainstay of surgical treatment for ampullary malignancies and complete resection of the lesion is mandatory ${ }^{15}$. Surgical excision by partial nephrectomy (nephron-sparing surgery) has been recommended for small RCCs. The surgical technique can be performed either through open or laparoscopic approach. In our case, open partial nephrectomy was performed to interfere both tumors by the decision of multidisciplinary decision team including general surgery and urology. The early diagnosis of RCC is important for favorable prognosis in that 10-year cancer -specific survival rates are $97 \%$ for T1a RCC and 57\% for T1b RCC ${ }^{16}$. Long-term survival of ampullary carcinoma remains low. 5-year survival rate for ampullary carci- 
noma is $40 \%{ }^{17}$. However, our patient died 4 days after the operation due to cardiac problems.

\section{CONCLUSION}

The coexistence of synchronous renal cell carcinoma with adenocarcinoma of ampulla of Vater is a very rare condition. Clinicians must be careful because the primary tumor can be accompanied by a secondary tumor. In such cases, curative surgery can be performed.

\section{REFERENCES}

1. Maruyama T, Nakasone T, Maruyama N, Matayoshi A, Arasaki A. Synchronous quadruple multiple primary cancers of the tongue, bilateral breasts, and kidney in a female patient with a disease-free survival time of more than 5 years: a case report. World J Surg Oncol. 2015;13:263. [CrossRef]

2. Oh SJ, Bae DS, Suh BJ. Synchronous triple primary cancers occurring in the stomach, kidney, and thyroid. Ann Surg Treat Res. 2015;88:345-8. [CrossRef]

3. Komiyama S, Nishio E, Ichikawa R, et al. Asymptomatic synchronous quintuple primary cancers. Gynecol Obstet Invest. 2012;74:324-8. [CrossRef]

4. Kim SH, Park BS, Kim HS, Kim JH. Synchronous quintuple primary gastrointestinal tract malignancies: case report. World J Gastroenterol. 2017;23:173-7. [CrossRef]

5. American Cancer Society. Kidney cancer. 2018. Available from: https://www.cancer.org/cancer/kidney-cancer/ about/key-statistics.html

6. Siegel R, Ma J, Zou Z, Jemal A. Cancer statistics. CA Cancer J Clin. 2014;64:9-29. [CrossRef]
7. Crist DW, Sitzmann JV, Cameron JL. Improved hospital morbidity, mortality, and survival after the Whipple procedure. Ann Surg. 1987;206:358-65. [CrossRef]

8. Ponka JL, Uthappa NS. Carcinoma of the ampulla of vater. Am J Surg. 1971;121:263-70. [CrossRef]

9. Boxer RJ, Waisman J, Lieber MM, Mampaso FM, Skinner DG. Non-metastatic hepatic dysfunction associated with renal carcinoma. J Urol. 1978;119:468-71. [CrossRef]

10. \wik G, Wallner G, Skoczylas T, Ciechanski A, Zinkiewicz K. Cancer antigens $19-9$ and 125 in the differential diagnosis of pancreatic mass lesions. Arch Surg. 2006;141:968-73. [CrossRef]

11. Materne R, Van Beers BE, Gigot JF, et al. Extrahepatic biliary obstruction: magnetic resonance imaging compared with endoscopic ultrasonography. Endoscopy. 2000;32:3-9. [CrossRef]

12. Geier A, Nguyen HN, Gartung C, Matern S. MRCP and ERCP to detect small ampullarycarcinoma. Lancet. 2000;356:1607-8. [CrossRef]

13. Hall TJ, Blackstone MO, Cooper MJ, Hughes RG, Moossa AR. Prospective evaluation of endoscopic retrograde cholangiopancreatography in the diagnosis of periampullary cancers. Ann Surg.1978;187:313-7. [CrossRef]

14. Wakabayashi H, Akamoto S, Yachida S, et al. Significance of fluorodeoxyglucose PET imaging in the diagnosis of malignancies in patients with biliary stricture. Eur J Surg Oncol. 2005;31:1175-9. [CrossRef]

15. Aiura K, Shinoda M, Nishiyama R. Surgical technique for complete resection of the extrahepatic portion of the common bile duct and the ampulla of Vater for tumors of the ampulla of Vater. J Hepatobiliary Pancreat Sci. 2011;18:276-81. [CrossRef]

16. Yamashita S, Oikawa K, Aizawa M, et al. Long-term prognosis of incidental renal cell carcinoma--clinical analysis of renal cell carcinoma detected by our health checkup. Nihon Hinyokika Gakkai Zasshi. 2007;98:614-8.

17. Klein F, Jacob D, Bahra M, et al. Prognostic factors for long-term survival in patients with ampullary carcinoma: The results of a 15-year observation period after pancreaticoduodenectomy. HPB Surg. 2014;2014:970234. [CrossRef] 